\title{
Crisis Management and Disaster Prevention Systems at Special Needs Schools During the Great East Japan Earthquake
}

\begin{abstract}
Mari TANAKA*
Kyushu University, Japan

The present study aimed to report on how schools responded after the Great East Japan Earthquake in 2011 from the perspective of school management and to discuss crisis management and disaster prevention systems for special needs schools. This survey discovered that four schools served as shelters in one form or another. Yet, none of the schools had stockpile of food and school staff therefore made every effort to address the issues of food, water, blankets, and sanitation. A review of crisis management and disaster prevention systems for children with special needs should be undertaken in cooperation with government administrative offices.
\end{abstract}

Key Words: disability, disaster, special needs schools, crisis management

\section{Introduction}

The Great East Japan Earthquake occurred on 11 March, 2011 was a disaster of unexpected scale, and consequently, there were cases where existing crisis management and disaster prevention systems did not function in various fields, including education, government, and welfare. In the setting of education, however, schools are required to serve as safe and secure places and must be prepared to deal with the unexpected. This is especially true in the education of children with disabilities, given that higher levels of preparation and training are routinely needed. Children with disabilities are physically, psychologically, and educationally vulnerable in a disaster (Peek \& Stough, 2010). However, only a few studies (e.g., Miyamoto, 1996) have addressed crisis management and disaster prevention systems in the context of education for children with disabilities, based on the experiences of the Great HanshinAwaji Earthquake in 1995 and the Niigata Prefecture Chuetsu Earthquake in 2004. Miyamoto (1996) inter-

\footnotetext{
* Corresponding Author

Mailing Address: 744 Motooka, Nishi-ku, Fukuoka 819-0395, Japan

E-mail Address: tanakamari@artsci.kyushu-u.ac.jp

Received August 19, 2016, Accepted February 18, 2017

DOI: $10.6033 /$ specialeducation.6.103
}

viewed 10 special needs schools in a seriously damaged area after the former earthquake. He found that children with autism had behavioral problems, were physically vulnerable, and could not use the evacuation center. However, school management at the time of disaster, situations during the earthquake, and temporary shelter management remain unclear. Thus, the aims of the present study were to report on how schools responded after the earthquake from the perspective of school management and to discuss crisis management and disaster prevention systems for special needs schools.

\section{Methods}

\section{Participants}

Participants were eight special needs schools in Miyagi Prefecture that were most seriously affected by the Great East Japan Earthquake. Interviewees were principals, vice principals, senior teachers, or other teachers who could recall the situation and responses at their schools during the disaster.

\section{Procedure}

The survey period was November to December 2011. A qualitative research methodology was used in this study. The author visited each participating school once or twice and conducted semi-structured interviews. Interviews lasted for $2-5 \mathrm{hrs}$. at each 
school. The survey covered to collect information about school management for safety confirmation at the time of disaster, situations of pupils and school staffs during the earthquake, and temporary shelter management to care pupils and their family members.

\section{Results}

\section{Situations at the Time of the Earthquake}

Pupils. Graduation ceremonies were held that day at six of the eight schools and no pupils were at school when the earthquake occurred. Most pupils from one of the remaining two schools were $10 \mathrm{~min}$ away from the school on their way home when the earthquake struck. One of the schools attempted, without success, to contact the driver of a school bus on his/her mobile phone because the bus was in a coastal area. However, using the radio system of another bus, which had already returned to school, the headquarters' instruction to return to school was conveyed to the driver and the bus was driven back to the school. In another school, pupils who were not graduating were at school at that time and followed the procedures of their evacuation manual.

Shelters. Only one of the eight schools was a designated shelter for the municipality, and this school served as a shelter after the earthquake struck. However, no staff from the municipality were dispatched and therefore the school staff ran the shelter themselves. Another school, although not designated as an official shelter, offered its buildings to local residents for this purpose. Two other schools opened the school for those pupils who could not return home; they provided shelter to pupils and their family members but not to residents.

Actions of school staff. After safety was confirmed inside and outside of school buildings all the schools set up disaster management headquarters. Apart from the two schools that set up shelters, all staff members at the remaining six schools, except those who were in charge of the disaster management headquarters, were instructed to go home to check the safety of their family members and houses. From the beginning of the following week, March 14, in spite of difficulties caused by fuel shortages and being victims of the disaster themselves with houses and family affected, many staff went to their schools using various means of transportation and helped with the restoration of their schools and the confirmation of pupils' safety. Management staff in most schools stayed overnight at their schools from a few to ten days after the earthquake occurred.

\section{Management of Shelters}

One school was designated as an official shelter, one school opened its facilities to residents, and two schools offered shelter to pupils and their family members. All four schools serving as shelters were run by the school staff but no stockpile of food or relief supplies were initially available.

School A was designated as an official shelter and duly set up a formal shelter soon after the earthquake occurred. However, pupils were at school at that time and the school staff had to deal with both pupils and resident evacuees. Additionally, the school did not have any stockpile of food and therefore had to offer meals using the food stored for school lunches. They had 100 evacuees at the peak time and operated the shelter for 14 days. They devised the following approach in managing the shelter: Spaces for resting and living were separated to help elderly people and infants; they nominated a contact person who organized the rotations of school staff for the work at the shelter.

School B opened its site to local residents based on the decision of staff in its disaster management headquarter. A shelter was set up once it was decided "to open our doors to local residents who came for help." This was based on the principal's view that "schools coexist with the local area" and all the staff agreed with this decision. The school accepted 81 evacuees, including 13 of their pupils at the peak time, and operated the shelter for 59 days. They also accepted 21 elderly people from local hospitals, some of whom needed nursing care. The school staff was divided into some groups to manage the shelter. After a week of running the site, school staff from other schools were dispatched there by the prefectural board of education. At this point, some of the original shelter staff were able to go home for the first time since the earthquake. When managing the shelter, in order to make evacuees comfortable, the staff divided evacuees into several groups and placed them in separate classrooms according to their needs: "in need of full assistance," "in need of partial assistance," "in need of special support due to mental illness, autism, or severe and multiple disabilities that make health 
management difficult."

School C provided a shelter for pupils who could not go home. They helped 29 pupils and four parents/ guardians who were on buses that returned to the school after the earthquake and who remained for eight days. As they did not have any stockpile of food, apart from food stored at the time for school lunches, the school staff went to town to buy or collect food from the second day onwards.

School D provided shelter for pupils and their family members who were affected by the disaster and asked for help. When school staff visited shelters to confirm the safety of their pupils and families, they told those who were affected by the tsunami that they could come to the school building for shelter. They helped three families who stayed in school for 14 days, but they did not have any stockpile of food when the earthquake struck. They therefore informed the local board of education on March 12 that they were looking after children and the board sent relief goods, including food.

\section{Discussion}

It was originally reported that among special needs schools in Miyagi Prefecture, only school B served as a shelter. However, this survey discovered that four schools served as shelters in one form or another. Yet, none of the schools had stockpile of food and school staff members therefore made every effort to address the issues of food, water, blankets, and sanitation. Most schools did not have pupils in class at the time of the earthquake and tsunami, so the situation would have been different if pupils were in class. This suggests that, firstly, it is necessary to have enough food, water and blankets for all pupils to live on for a few days, to have a power generator (none of the schools had one at the time), and radio communication systems at schools. Furthermore, depending on the condition of pupils, other items such as disposable diapers and medicine should be stored at schools. There is an urgent need to build a system in which stockpile is kept at school all the time and replenished regularly, and to review school evacuation manuals including the roles of staff who are involved with the management of shelters. The schools in this survey had prepared for disaster management in cooperation with parent-teacher associations and other groups. However, government administration was shown to have lagged behind in this aspect. That was because only one school was designated as an official shelter.

A review of crisis management and disaster prevention systems for children with special needs should be undertaken in cooperation with government administrative offices.

\section{Acknowledgment}

I would like to thank all the teachers of special needs schools who cooperated in this study. I am grateful to many sources of support during the course of this research, in particular, Mari Umeda and Kentaro Satoh.

\section{References}

Miyamoto, S. (1996) Support to problem in children with disabilities during disaster. Research-Aid Paper of the Yasuda Life Welfare Foundation, 31, 114-121. (in Japanese)

Peek, L. \& Stough, L. M. (2010) Children with disabilities in the context of disaster: A social vulnerability perspective. Child Development, 81, 1260-1270. 